\title{
ORIGINAL
}

\section{Expression of Hsp47 in Fibroblasts Derived from Fetal and Neonatal Rat Tongues}

\author{
Seigo Ohba*, Tomomi T. Baba**, Takayuki K. Nemoto** and Tsugio Inokuchi* \\ ${ }^{*}$ Division of Oral and Maxillofacial Surgical Reconstruction and Functional Restoration, \\ Department of Developmental and Reconstructive Medicine, \\ Graduate School of Biomedical Sciences, Nagasaki University \\ (Chief : Prof. Tsugio Inokuchi) \\ **Division of Oral Molecular Biology, Department of Developmental and Reconstructive Medicine, \\ Graduate School of Biomedical Sciences, Nagasaki University \\ (Chief : Prof. Takayuki K. Nemoto) \\ *, **1-7-1 Sakamoto, Nagasaki 852-8588, Japan
}

(Received on June 21, 2002 ; Accepted on September 25, 2002)

Key words : Hsp47/transforming growth factor $-\beta 1 /$ wound healing/collagen

\begin{abstract}
Scar formation, caused by the abnormal expression and accumulation of collagen molecules accompanying the expression of heat shock protein 47 (Hsp47), a collagen-specific molecular chaperone, is a serious problem after surgery in the postnate, whereas in the fetus, the wound heals without scarring. In this study, we compared the expression patterns of $\mathrm{Hsp} 47$ and type I and type III collagens induced by TGF$\beta 1$ between fetal and neonatal fibroblasts in the primary cultures of rat tongues. In the neonate, high level expressions of both Hsp47 and collagen mRNAs and proteins were observed to be induced by TGF- $\beta$ 1, but not in the fetus. We performed a reporter assay using pLUC 5.5(III), which carried the enhancer/promoter region of the mouse Hsp47 gene, to compare promoter/reporter activity. In the neonate, high promoter/ reporter activity in fibroblasts treated with TGF- $\beta 1$ was observed, but was unchanged in the fetus. Thus, the expression of Hsp47 is enhanced by TGF- $\beta 1$ in the neonate but not in the fetus. This different Hsp47 expression pattern between the fetus and neonate appears to be attributed to the different transcriptional regulation of the gene. Elucidation of the regulatory mechanism of Hsp47 production in developmental processes may provide a therapeutic modality for the scarless healing of postnatal wounds.
\end{abstract}

抄録：コラーゲンの異常な発現と蓄積に起因する瘢痕形成は, 生後の外科処置後の深刻な問題である。一方, 胎児の創傷は瘃痕を形成することなく治瘑する。Heat shock protein 47 (Hsp47) はコラーゲンに特異的な分子 シャペロンであり, 痒痕部での発現の増加が認められる。本研究では, 胎仔および新生仔のラット舌由来の線維 芽細胞を用いて, TGF- $\beta 1$ に誘導される Hsp 47, I およびIII型コラーゲンの発現パターンを比較検討した。新生 仔由来線維芽細胞では, TGF- $\beta 1$ 処理により Hsp47 およびコラーゲンの発現は mRNA, タンパク質ともに增加 した。これに対して, 胎仔由来線維芽細胞ではそれらの増加は認められなかった。さらに, プロモーター/レポー ター活性を比較するために, マウス Hsp47 遺伝子のエンハンサー/プロモーター領域を含んだ pLUC 5.5 (III) を 用いてレポーターアッセイを行った。その結果, 新生仔由来線維芽細胞では TGF- $\beta 1$ 処理により高い活性が認め られたが, 胎仔由来線維芽細胞では認められなかった。以上のことより, Hsp47 の発現は新生仔ラットでは TGF$\beta 1$ により増加することが明らかになった。さらに, 胎仔と新生仔における Hsp47 の発現様相の差は, 遺伝子の 転写レベルですでに存在することが明らかになった。個体発生および発育過程における Hsp47 生成のメカニズム の解明は, 生後の創傷を無瘯痕性に治痣させる治療法に寄与すると思わ机る。 


\section{Introduction}

Heat shock protein 47 (Hsp47), a $47-\mathrm{kDa}$ stress protein, is a molecular chaperone, which is localized in the endoplasmic reticulum (ER) as inferred from the presence of a carboxyl-terminal RDEL sequence similar to the ER retrieval signal, $\mathrm{KDEL}^{1-3)}$. Hsp47 is an essential protein for the synthesis and processing of various types of collagens ${ }^{4,5}$. Collagen-producing cells always accompany the expression of $\mathrm{Hsp} 47$, but conversely, non-producing cells do not ${ }^{1,6-10}$.

There is a remarkable morphological and biochemical difference in the wound healing process between fetal and neonatal animals. Neonatal skin wounds heal with scar formation, whereas fetal skin wounds show minimal inflammatory response and heal without scar formation, fibrosis and contracture ${ }^{11-13)}$. Scar formation is characterized by an abnormal deposition and placement of collagen fibers, especially type I and type III collagens, accompanied with an increased expression of Hsp47 $7^{14,15}$.

It has been shown that fetal scarless wound repair is not attributed to systemic factors involved in the immune system, serum, or amnionic fluid. The capacity for scarless healing is considered to be inherent in fetal tissue itself, and fibroblasts are thought to be the main effectors of scarless healing in fetal tissues ${ }^{16-23)}$. However, the details of this mechanism are largely unknown.

Scar formation during skin wound healing of neonates has been reported to be closely related to the activity of TGF- $\beta$ family cytokines ${ }^{24}$. In particular, TGF- $\beta 1$ is a key cytokine involved in the initiation and termination of tissue repair ${ }^{25,26)}$ and has important roles in wound healing, which accompanies the deposition of collagen and other extracellular matrix components ${ }^{27}$. However, the over-expression of TGF- $\beta 1$ during neonatal wound healing causes the enhanced expression of Hsp47 and type I and III collagens.

The aim of this study was to elucidate the mecha. nism of different expression patterns of Hsp47 as well as type I and III collagens between fetal and neonatal fibroblasts.

\section{Materials and Methods}

\section{Primary cell culture and treatment with recombinant human TGF- $\beta 1$}

Fibroblasts outgrown from the healthy tongues of fetuses (17-day gestation) and neonates of SpragueDawley (SD) rats (gestation term $=21$ days) were cultured in Dulbecco's Modified Eagle's Medium (DMEM) (Nissui, Japan) containing 10\% fetal bovine serum (FBS) (Invitrogen life technologies, California, U.S.A.) and $1 \%$ penicillin-streptomycin (Invitrogen life technologies) in 100-mm plates under humidified $5 \% \mathrm{CO}_{2}$ at $37^{\circ} \mathrm{C}$. The medium was changed twice a week and the cells were passaged with PBS (-) containing $0.02 \%$ trypsin (Invitrogen life technologies) and $0.25 \%$ EDTA. After $3-5$ passages, the penicillin-streptomycin solution was removed from the medium. All the following experiments were performed in $60-\mathrm{mm}$ plates. After cultivation in serumfree DMEM for $24 \mathrm{~h}$ to eliminate the effect of cytokines present in the serum, the cells were cultured in medium containing $10 \mathrm{ng} / \mathrm{m} l$ recombinant human TGF- $\beta$ 1 (R \& D Systems, Inc., Minneapolis, U. S. A.) up to $48 \mathrm{~h}$.

\section{Western blotting analysis}

Cells were dissolved in lysis buffer $[150 \mathrm{mM} \mathrm{NaCl}$, $50 \mathrm{mM}$ Tris- $\mathrm{HCl}: \mathrm{pH} \quad 8.0, \quad 0.1 \%$ Nonidet $\mathrm{P}-40$ containing $0.25 \%$ Protease Inhibitor Cocktail Tablets : Complete, Mini (Roche, Germany)] . Protein concentration was measured using a protein assay kit (Bio-Rad) according to the manufacturer's instructions. One $\mu \mathrm{g}$ of protein was applied per lane on a $10 \%$ SDS-polyacrylamide gel followed by electrophoresis $^{28)}$. Separated proteins were transferred to a nitrocellulose membrane (Bio Trace NT Blotting Membrane : Gelman Sciences Japan) ${ }^{29)}$. After blocking with $3 \%$ skim milk in Tris-buffered saline containing $1 \%$ Tween $20, \mathrm{pH} 7.4$ (TBS-T) for $30 \mathrm{~min}$ at room temperature, the membranes were incubated with the mouse anti-Hsp47 (Colligin) monoclonal antibody (StressGen Biotechnologies Corp, Canada), goat antiprocollagen $\alpha 2$ ( I ) (Y-18) polyclonal antibody (Santa Cruz Biotechnology, Inc., U.S. A.), or goat anti- 
Table 1 Sequences of primers

\begin{tabular}{|c|c|c|c|c|c|c|}
\hline Gene & & Primer sequence & Base pairs & $\begin{array}{c}\text { Annealing } \\
\text { temperature }\left({ }^{\circ} \mathrm{C}\right)\end{array}$ & $\begin{array}{l}\text { Cycle } \\
\text { number }\end{array}$ & Reference \\
\hline \multirow[t]{2}{*}{ Hsp47 } & Forward & 5'-AAGATGGTAGACAACCGTGG-3' & 604 & 62 & 30 & 30) \\
\hline & Reverse & 5'-GTCTCGCATCTTGTCTCCCTT-3' & & & & \\
\hline \multirow[t]{2}{*}{$\alpha 1(\mathrm{I})$} & Forward & 5'-CCCACCCCAGCCGCAAAGAGT-3, & 352 & 51 & 35 & 31) \\
\hline & Reverse & 5'-TTGGGTCCCTCGACTCCTACA-3' & & & & \\
\hline \multirow[t]{2}{*}{$\alpha 1$ (III) } & Forward & 5'-TGCCCACAGCCTTCTACACCT-3' & 244 & 58 & 25 & 32) \\
\hline & Reverse & 5'-CAGCCATTCСТCССАСТCCAG-3' & & & & \\
\hline \multirow[t]{2}{*}{ GAPDH } & Forward & 5'-TCCСTCAAGATTGTCAGCAA-3' & 308 & 55 & 30 & 33) \\
\hline & Reverse & 5'-AGATCCACAACGGATACATT-3' & & & & \\
\hline
\end{tabular}

$\alpha 1$ (I) and $\alpha 1$ (III) : procollagen $\alpha 1$ (I) and $\alpha 1$ (III), respectively, GAPDH : glyceraldehyde-3-phosphate dehydrogenase.

procollagen $\alpha 1$ (III) (N-18) (Santa Cruz Biotechnology, Inc.) at $1: 4000$ dilution overnight at $4^{\circ} \mathrm{C}$. Proteins were detected with ECL Western blotting detection reagents (Amersham Pharmacia Biotech Inc. : U. K.) and visualized using an enhanced chemiluminescence system (ECL : Amersham Pharmacia Biotech Inc.). The relative density of the protein bands was quantified using a Scion Image. The density of a band untreated with TGF- $\beta 1(0 \mathrm{~h})$ was set as 1 .

\section{Reverse transcription-polymerase chain reac- tion (RT-PCR)}

Total RNA was extracted from cultured fibroblasts using ISOGEN (Wako, Japan). Reverse transcriptionPCR was carried out with total RNA $(0.5 \mu \mathrm{g}$ for Hsp47, $3 \mathrm{ng}$ for procollagen $\alpha 1$ ( I ) and $10 \mathrm{ng}$ for procollagen $\alpha 1$ (III)) by SUPERSCRIPT One-Step RT-PCR with PLASTINUM Taq (Invitrogen life technologies). Samples were incubated in a PCR Thermal Cycler (PERSONAL, TaKaRa) at $51-62^{\circ} \mathrm{C}$ for 25-35 cycles, depending on the primer sets (see Table 1). The PCR products were separated by electrophoresis on a $1.6 \%$ agarose gel and the bands were visualized by ethidium bromide staining ${ }^{34}$. The density of each band was quantified using a Scion Image. The density of the band untreated with TGF$\beta 1(0 \mathrm{~h})$ was set as 1 .

\section{Transient transfection of a Hsp47 gene reporter plasmid}

Cells were plated at a density of $1 \times 10^{5} / 60-\mathrm{mm} /$ culture dish. After being cultured for $20 \mathrm{~h}$, cells were transfected by the calcium phosphate method (DAC30 : EUROGENTEC BEL., Belgium) with $2.5 \mu \mathrm{g}$ of pLUC 5.5 (III) ${ }^{35)}$ as a reporter plasmid for the Hsp47 gene. One $\mu \mathrm{g}$ of pRL-TK (Wako) was co-transfected as the internal control to normalize the variation in transfectional efficiency. After $4 \mathrm{~h}$, the medium with the transfection precipitate was replaced with fresh DMEM containing $10 \%$ FBS. After $14 \mathrm{~h}$, the medium was changed to serum-free conditions to eliminate the effect of cytokines present in the serum. Cells were further incubated for $24 \mathrm{~h}$. TGF- $\beta 1(10 \mathrm{ng} / \mathrm{ml})$ was then added and the cells were harvested after $24 \mathrm{~h}$. Quantification of the luciferase activity was carried out with a Lumat LB 9501 (Berthold) as described previously ${ }^{35}$. The activity of pRL-TK (internal con. trol) was set as 100.

\section{Statistics}

All of the values were expressed as the mean \pm S. D. Statistical significance was evaluated by Student's ttest.

\section{Results}

\section{Western blotting analysis}

Immunoblotting analysis revealed a $47-\mathrm{kDa}$ band, specific for Hsp 47. The intensity was unchanged in 


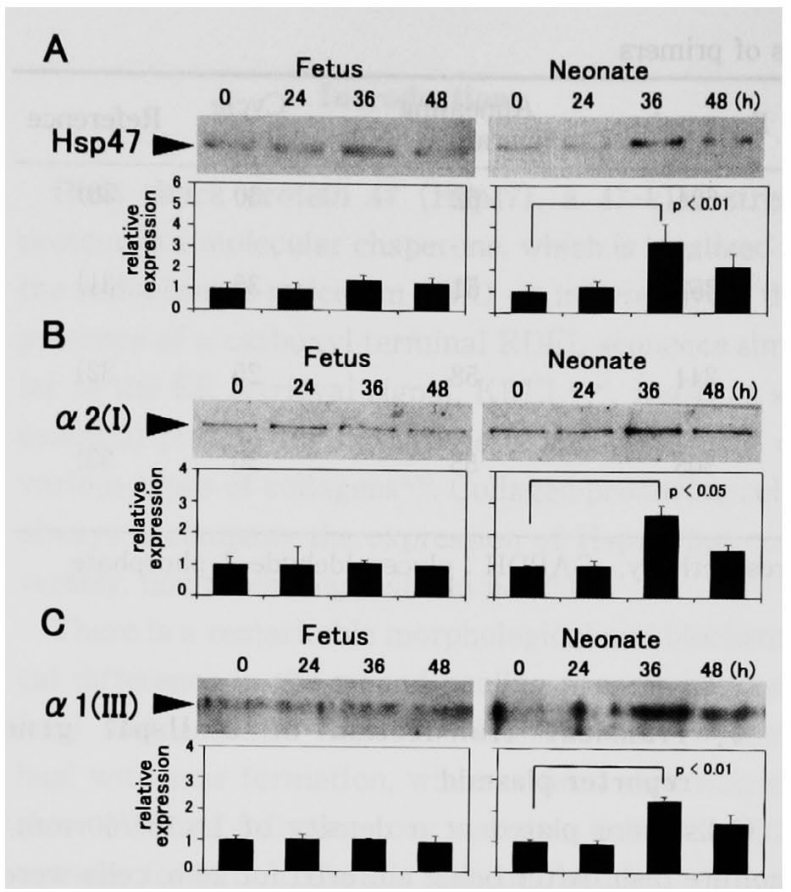

Fig. 1 Western blotting analysis of Hsp47 and type I and type III collagens.

(A) Hsp47, (B) procollagen $\alpha 2$ ( I ) and (C) procollagen $\alpha 1$ (III) proteins were immunoblotted after the treatment of (left) fetal and (right) neonatal fibroblasts with $10 \mathrm{ng} /$ $\mathrm{m} l \mathrm{TGF}-\beta 1$ for $0-48 \mathrm{~h}$. Values are expressed as means \pm S. D. $(n=6)$.

the fibroblasts derived from the fetal tongue following treatment with $\mathrm{TGF}-\beta 1(0,1,5$ and $10 \mathrm{ng} / \mathrm{m} l)$. In contrast, in the neonatal fibroblasts, the expression increased in a concentration-dependent manner for TGF- $\beta 1$ at $36 \mathrm{~h}$ (data not shown). When the cells were exposed to TGF- $\beta 1$ at $10 \mathrm{ng} / \mathrm{m} l$ for $0,24,36$ and $48 \mathrm{~h}$, the Hsp47 expression was unchanged in the fetal fibroblasts, while in the neonatal fibroblasts, the intensity of the Hsp47 band treated with TGF- $\beta 1$ for $36 \mathrm{~h}$ was 3.3 times greater than that of the non-treated specimen (Fig. $1 \mathrm{~A}$ ). The relative expression level of $\mathrm{Hsp} 47$ in the fetal and neonatal fibroblasts at $0 \mathrm{~h}$ was almost identical ( $1: 0.95)$. Concomitantly, TGF- $\beta 1$ increased the expression of procollagens $\alpha 2$ (I) and $\alpha 1$ (III), 2.6- and 2.3-fold, respectively, in the neonatal fibroblasts after treatment with TGF- $\beta 1$ for $36 \mathrm{~h}$, but not in the fetal cells (Fig. $1 \mathrm{~B}, \mathrm{C}$ ).

\section{RT-PCR analysis}

The Hsp47 mRNA level slightly decreased during

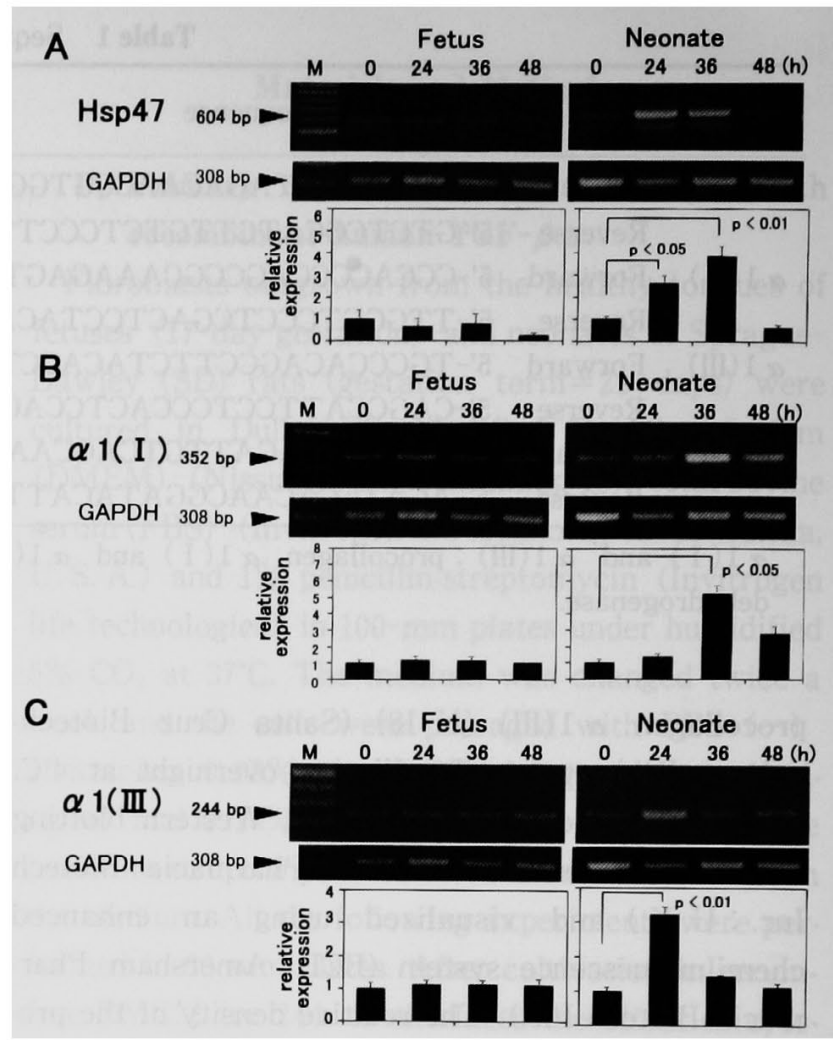

Fig. 2 RT-PCR analysis of $\mathrm{Hsp} 47$ and procollagen $\alpha 1$ (I) and $\alpha 1$ (III) mRNAs.

RT-PCR was performed for (A) Hsp47, (B) procollagen $\alpha 1$ ( I ), (C) $\alpha 1$ (III) mRNAs after the treatment of (left) fetal and (right) neonatal fibroblasts with TGF- $\beta 1$ for $0-48 \mathrm{~h}$. Values are expressed as means \pm S. D. $(n=6) . M$, 100-bp ladder (TAKARA SHUZO CO.).

the TGF- $\beta 1$ treatment period in fetal fibroblasts (Fig. 2 A). There was also little difference in the expression levels of procollagen $\alpha 1$ (I) and $\alpha 1$ (III) mRNAs in fetal fibroblasts with or without TGF- $\beta 1$ treatment (Fig. 2 B, C). However, in neonatal fibroblasts, the amount of Hsp47 mRNA after treatment with TGF$\beta 1$ for 24 and $36 \mathrm{~h}$ was 2.6 - and 3.8-fold higher than that of non-treated cells, respectively (Fig. $2 \mathrm{~A}$ ). In the case of procollagen $\alpha 1$ ( I ), the expression was 5.2and 2.8-fold increased after 36 and $48 \mathrm{~h}$ treatments, respectively (Fig. $2 \mathrm{~B}$ ), and the procollagen $\alpha 1$ (III) expression was 3.2-fold higher at $24 \mathrm{~h}$ (Fig. $2 \mathrm{C}$ ). Thus, the expressions of Hsp47 protein and mRNA were responsive to $\mathrm{TGF}-\beta 1$ in the fibroblasts derived from the neonatal but not the fetal tongue. Apparently, the increase in the protein contents was either 
preceded by the increase in the Hsp47 and procollagen $\alpha 1$ (III) mRNAs or coincided with the increase in procollagen $\alpha$ 1 ( I ) mRNA.

\section{Reporter assay}

In the neonatal fibroblasts, the luciferase activity was 2.5 -fold up-regulated by TGF- $\beta 1$, while in the fetal fibroblasts, the activity was not altered (Fig. 3). This finding was consistent with the results of Western blotting (Fig. 1) and RT-PCR analyses (Fig. 2), and further confirmed that the expression of Hsp47 mRNA was directly enhanced by TGF- $\beta 1$.

\section{Discussion}

Why does a fetal wound heal without a scar? Many studies have attempted to answer this question, but it remains to be elucidated. We recently reported that the up-regulation of type I collagen and Hsp47 expression is directly responsible for scar formation in neonatal rat wound ${ }^{36}$. Subsequently, in this study, we compared the expression of Hsp47 between fibroblasts derived from fetal and neonatal tissues.

Type I and III collagens are the main components of the extracellular matrix in the scar, and heat shock protein 47 (Hsp47) is also co-expressed in this region ${ }^{1,8)}$. Hsp47 is a collagen-specific molecular chaperone and an essential proteins for collagens syntheses. Therefore, it was reasonably assumed that the different patterns of Hsp47 expression between the fetus and neonate were responsible for their resultant wound healing.

We used 17-day gestation rats to propagate the fibroblasts, because the transitional point from scarless healing to scar formation is at $18-19$ days of gestation in rats $^{37,38)}$. It has been reported that the expression of TGF- $\beta 1$ was scarcely altered during fetal wound healing ${ }^{29)}$, and this has been considered to be one of the reasons why fetal wounds heal without scar. We used TGF- $\beta 1$ as the inducer of collagen production, because it is an important factor in wound healing, and moreover, its over-expression induces scar formation during wound healing ${ }^{39-41}$.

In fetal fibroblasts, TGF- $\beta 1$ had little effect on the expression of Hsp47 and type I and III collagens. In

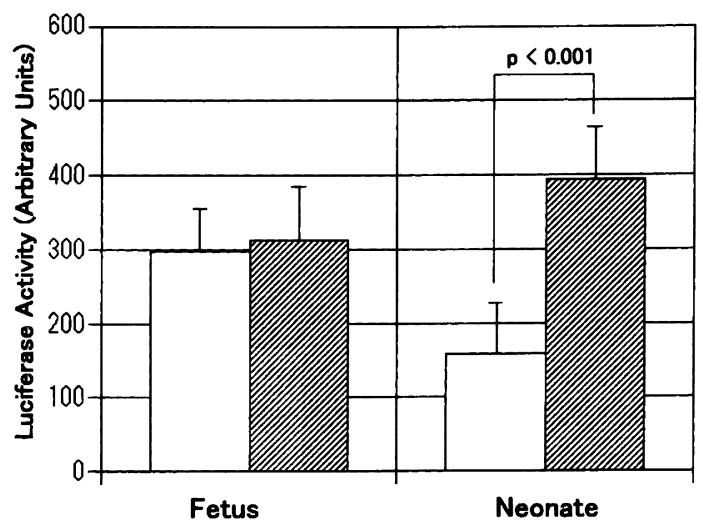

Fig. 3 Reporter assay with pLUC 5.5(III).

The luciferase activity of fetal and neonatal fibroblasts, transfected with pLUC 5.5(III) was determined as described in Materials and Methods. Transfected cells treated (open) without or (hatched) with $\mathrm{TGF}-\beta 1$ for $24 \mathrm{~h}$. Values are expressed as means \pm S. D. $(n=6)$.

contrast, in the neonatal fibroblasts, they were increased by TGF- $\beta 1$ at both the protein and mRNA levels. Thus, the coordinated expression of Hsp47 and collagens $^{1,8)}$ was maintained, when the fibroblasts were treated with TGF- $\beta 1$ in vitro. The difference in their biological behavior appears to be maintained in fibroblasts derived from fetal and neonatal rat tongues for at least several passages.

In order to determine whether TGF- $\beta 1$ directly modulates the expression of Hsp47, we performed a transfection assay of the fibroblasts with pLUC 5.5(III). The mouse Hsp47 gene consists of 6 exons and 5 introns, of which pLUC 5.5(III) encodes the first and second introns and the first exon followed by the luciferase gene ${ }^{35)}$. The luciferase activity of pLUC 5.5(III) has been reported to be up-regulated in Hsp47-producing cells but not in nonproducing cells ${ }^{35}$. This study also demonstrated the gene activation of Hsp47 by TGF- $\beta 1$ in the neonatal fibroblasts.

The expression of TGF- $\beta$ receptor I (T $\beta \mathrm{RI})$ was unchanged by TGF- $\beta 1$ in both neonatal and fetal fibroblasts (Ohba, S. and Inokuchi, T., unpublished observation). Durham, L. A. 3 rd., et al. reported that, as fibroblasts differentiate during development from embryo through fetus on to adult, there is a progressive reduction in the number of $\mathrm{T} \beta \mathrm{Rs}$ with adult fibroblasts expressing the minimum ${ }^{42}$. Since TGF- $\beta 1$ 
is an essential growth factor in ontogenesis, it is not considered that $\mathrm{T} \beta \mathrm{R}$ in the fetus is inactive. Altogether, it is not presumed that the number of $\mathrm{T} \beta \mathrm{Rs}$ are pertinent to the different expression of Hsp47 induced by TGF- $\beta 1$ between fetal and neonatal fibroblasts.

This study demonstrated that scar formation in the neonatal wound is partly attributed to TGF- $\beta 1$. However, this study also revealed that the scarless healing characteristic of a fetal wound may be independent of the concentration of TGF- $\beta 1$, because exogeneous TGF- $\beta 1$ did not induce the expression of Hsp47 and collagens. Accordingly, unknown factor (s) may contribute to this phenomenon. There are several possibilities for this hypothetical factor (s) : The first possibility is that this might involve the transcription factor (s) or suppressor(s) of genes for $\mathrm{Hsp} 47$ and collagenous proteins. Hirata, et $a l .{ }^{35)}$ reported the presence of the Hsp47 gene-binding factor specific for Hsp47-producing cells. Accordingly, it is of great interest to investigate the developmental kinetics of this factor during gestation and the neonatal period. Secondly, it is conceivable that a factor(s) may play a role downstream of TGF signaling, eg, Smad family proteins. For instance, there is an inhibitory Smad in TGF $-\beta$ signaling, Smad7, and the addition of IFN $-\gamma$ induces Smad7 expression, causing the suppression of the collagen expression ${ }^{43}$.

\section{Conclusion}

The expression of Hsp47 as well as type I and III collagens is induced by TGF- $\beta 1$ in neonatal but not fetal fibroblasts. This process appears to be readily controlled at the transcriptional level.

\section{Acknowledgments}

We thank Drs. Kazuhiro Nagata (Kyoto University) and Akihiro Wada (Nagasaki University) for providing plasmids. We are also grateful to Drs. Hisazumi Ikeda, Takayoshi Tobita and Zuo-lin Wang for technical support. This study was supported by Grants-inAid for Scientific Research from the Japanese Ministry of Education, No. 12877329.

\section{References}

1) Nagata, K. : Hsp47 : a collagen-specific molecular chaperone. Trends Biochem. Sci. 21 : 22-26, 1996.

2) Saga, S., Nagata, K., Chen, W. T. and Yamada, K. $\mathrm{M}$ : : $\mathrm{pH}$-dependent function, purification, and intracellular location of a major collagen-binding glycoprotein. J. Cell Biol. 105 : 517-527, 1987.

3) Nagata, K. : Expression and function of heat shock protein $47:$ a collagen-specific molecular chaperone in the endoplasmic reticulum. Matrix Biol. 16: 379-386, 1998.

4) Nagai, N., Hosokawa, M., Itohara, S., Adachi, E., Matsushita, T., Hosokawa, N. and Nagata, K. : Embryonic lethality of molecular chaperone hsp47 knockout mice is associated with defects in collagen biosynthesis. J. Cell Biol. 150 : 1499-1506, 2000.

5) Dafforn, T. R., Della, M. and Miller, A.D. : The molecular interactions of heat shock protein 47 (Hsp47) and their implications for collagen biosynthesis. J. Biol. Chem. 276 : 49310-49319, 2001.

6) Nakai, A., Satoh, M., Hirayoshi, K. and Nagata, $\mathrm{K}$. : Involvement of the stress protein HSP47 in procollagen processing in the endoplasmic reticulum. J. Cell Biol. 117 : 903-914, 1992.

7) Tomita, M., Yoshizato, K., Nagata, K. and Kitajima, T.: Enhancement of secretion of human procollage I in mouse HSP47-expressing insect cells. J. Biochem. (Tokyo) 126 : 1118-1126, 1999.

8) Kuroda, K., Tsukifuji, R. and Shinkai, H. : Increased expression of heat-shock protein 47 is associated with overproduction of type I procollagen in systemic sclerosis skin fibroblasts. J. Invest. Dermatol. 111 : 1023-1028, 1998.

9) Nagata, K. : Expression and function of heat shock protei 47 : a collagen-specific molecular chaperone in the endoplasmic reticulum. Matrix Biol. 16: 379-386, 1998.

10) Lamande, S. R. and Bateman, J. F. : Procollagen folding and assembly: the role of endoplasmic reticulum enzymes and molecular chaperones. Semin. Cell Dev. Biol. 10 : 455-464, 1999.

11) Siebert, J. W., Burd, A. R., McCarthy, J. G., Weinzweig, J. and Ehrlich, H. P. : Fetal wound healing : a biochemical study of scarless healing. Plast. Reconstr. Surg. 85 : 495-504, 1990.

12) Lorenz, H. P. and Adzick, N.S. : Scarless skin wound repair in the fetus. West. J. Med. 159: 
350-355, 1993.

13) Nodder, S. and Martin, P.: Wound healing in embryos:a review. Anat. Embryol. (Berl) 195: 215-228, 1997.

14) Wang, J. F., Olson, M. E., Reno, C. R., Kulyk, W., Wright, J. B. and Hart, D. A. : Molecular and cell biology of skin wound healing in a pig model. Connect Tissue Res. 41: 195-211, 2000.

15) Masuda, H., Fukumoto, M., Hirayoshi, K. and Nagata, K. : Coexpression of the collagen-binding stress protein HSP 47 gene and the alpha 1( I ) and alpha 1(III) collagen genes in carbon tetrachlorideinduced rat liver fibrosis. J. Clin. Invest. 94: 2481-2488, 1994.

16) Lin, R. Y., Sullivan, K. M., Argenta, P. A., Meuli, M., Lorenz, H. P. and Adzick, N. S. : Exogenous transforming growth factor-beta amplifies its own expression and induces scar formation in a model of human fetal skin repair. Ann. Surg. 222 : 146-154, 1995.

17) DePalma, R. L., Krummel, T. M., Durham, L. A. 3 rd., Michna, B. A., Thomas, R. L., Nelson, J. M. and Diegelmann, R.F.: Characterization and quantitation of wound matrix in the fetal rabbit. Matrix 9:224-231, 1989.

18) Igawa, H. H., Thinle, C., Funayama, E. and Sugihara, T. : Fetal scarless wound healing. Biomedical Perspectives 9:225-232, 2000. (in Japanese)

19) Lorenz, H. P., Longaker, M. T., Perkocha, L. A., Jennings, R. W., Harrison, M. R. and Adzick, N. S. : Scarless wound repair : a human fetal skin model. Development 114:253-259, 1992.

20) Longaker, M. T., Whitby, D. J., Ferguson, M. W., Lorenz, H. P., Harrison, M. R. and Adzick, N. S. : Adult skin wounds in the fetal environment heal with scar formation. Ann. Surg. 219 : 65-72, 1994.

21) Bleacher, J.C., Adolph, V. R., Dillion, P. W. and Krummel, T. M. : Isolated fetal mouse limbs: gestational effects on tissue repair in an unperfused system. J. Pediatr. Surg. 28 : 1312-1315, 1993.

22) Soo, C., Hu, F. Y., Zhang, X., Wnag, Y., Beanes, S. R., Lorenz, H. P., Hedrick, M. H., Mackool, R. J., Plaas, A., Kim, S. J., Longaker, M. T., Frevmiller, E. and Ting, K.: Differential expression of fibromodulin, a transforming growth factor-beta modulator, in fetal skin development and scarless repair. Am. J. Pathol. 157 : 423-433, 2000.

23) Coleman, C., Tuan, T. L., Buckley, S., Anderson, K. D. and Warburton, D. : Contractility, transforming growth factor-beta, and plasmin in fetal skin fibroblasts : role in scarless wound healing. Pediatr. Res. 43: 403-409, 1998.

24) Desmouliere, A., Geinoz, A., Gabbiani, F. and Gabbiani, G.: Transforming growth factor-beta 1 induces alpha-smooth muscle actin expression in granulation tissue myofibroblasts and in quiescent and growing cultured fibroblasts. J. Cell Biol. 122 : 103-111, 1993.

25) Younai, S., Nichter, L. S., Wellisz, T., Reinisch, J., Nimni, M. E. and Tuan, T. L. : Modulation of collagen synthesis by transforming growth factor-beta in keloid and hypertrophic scar fibroblasts. Ann. Plast. Surg. 33 : 148-151, 1994.

26) Lanning, D. A., Nwomeh, B. C., Montante, S. J., Yager, D. R., Diegelmann, R. F. and Haynes, J. H. : TGF-beta 1 alters the healing of cutaneous fetal excisional wounds. J. Pediatr. Surg. 34:695-700, 1999.

27) Nath, R. K., LaRegina, M., Markham, H., Ksander, G. A. and Weeks, P. M. : The expression of transforming growth factor type beta in fetal and adult rabbit skin wounds. J. Pediatr. Surg. 29:416-421, 1994.

28) Laemmli, U.K.: Cleavage of structural proteins during the assembly of the head of bacteriophage T 4. Nature 227:680-685, 1970.

29) Saga, S., Hamaguchi, M., Hoshino, M. and Kojima, K. : Expression of meta-vinculin associated with differentiation of chicken embryonal muscle cells. Exp. Cell Res. 156 : 45-56, 1985.

30) Clarke, E. P., Cates, G. A., Ball, E. H. and Sanwal, B. D. : A collagen-binding protein in the endoplasmic reticulum of myofibroblasts exhibits relationship with serine protease inhibitors: Rat heat-shock collagen-binding protein (gp 46). J. Biol. Chem. 266 : 17230-17235, 1991.

31) Waggett, A. D., Ralphs, J. R., Kwan, A. P., Woodnutt, D. and Benjamin, M. : Characterization of collagens and proteoglycans at the insertion of the human Achilles tendon. Matrix Biol. 16: 457-470, 1998.

32) Lovaud, S., Poirier, B., Mandet, C., Belair, M. F., Iriopoulou, T., Heudes, D., Bazin, R., Bariety, J., Myara, I. and Chevalier, J. : Inflammation is probably not a prerequisite for renal interstitial fibrosis in normoglycemic obese rats. Am. J. Physiol. Renal Physiol. 280 : F 683-694, 2001.

33) Ando, T., Okuda, S., Tamaki, K., Yoshitomi, K. and 
Fujishima, M. : Localization of transforming growth factor-beta and latent transforming growth factor-beta binding protein in rat kidney. Kidney Int. $47:$ 733-739, 1995.

34) Seth, A., Lee, B. K., Qi, S. and Vary, C. P. : Coordinate expression of novel genes during osteoblast differentiation. J. Bone Miner. Res. 15 : 1683-1696, 2000.

35) Hirata, H., Yamamura, I., Yasuda, K., Kobayashi, A., Tada, N., Suzuki, M., Hirayoshi, K., Hosokawa, N. and Nagata, K. : Separate cis-acting DNA elements control cell type- and tissue-specific expression of collagen binding molecular chaperone HSP47. J. Biol. Chem. 274 : 35703-35710, 1999.

36) Wang, Z. L., Inokuchi, T., Ikeda, H, Baba, T. T., Uehara, M., Kamasaki, N., Sano, K., Nemoto, K. T. and Taguchi, T. : Collagen-binding heat shock protein HSP47 expression during healing of fetal skin wounds. Int. J. Oral Maxillofac. Surg. 31 : 179-184, 2002.

37) Yoshimura, Y. and Nakajima, T. : Wound healing of fetus and neonate. Jpn. J. Pediatr. Surg. 29 : 1605-1609, 1997. (in Japanese)

38) Ihara, S., Motobayashi, Y., Nagao, E. and Kistler, A. : Ontogenetic transition of wound healing pattern in rat skin occurring at the fetal stage. Develop- ment $110: 671-680,1990$.

39) Terrell, T.G., Working, P. K., Chow, C.P. and Green, J.D. : Pathology of recombinant human transforming growth factor-beta 1 in rats and rabbits. Int. Rev. Exp. Pathol. 34: 43-46, 1993.

40) Zugmaier, G., Paik, S., Wilding, G., Knabble, C., Bano, M., Lupu, R., Deschauer, B., Simpson, S., Dickson, R. B. and Lippman, M. : Transforming growth factor beta 1 induces cachexia and systemic fibrosis without an antitumor effect in nude mice. Cancer Res. 51 : 3590-3594, 1991.

41) Yamamoto, T., Noble, N. A., Miller, D. E. and Border, W. A. : Sustained expression of TGF-beta 1 underlies development of progressive kidney fibrosis. Kidney Int. 45: 916-927, 1994.

42) Durham, L. A. 3 rd., Krummel, T. M., Cawthorn. J. W., Thomas, B. L. and Diegelmann, R. F. : Analysis of transforming growth factor beta receptor binding in embryonic, fetal, and adult rabbit fibroblasts. J. Pediatr. Surg. 24 : 784-788, 1989.

43) Huang, M., Sharma, S., Zhu, L. X., Keane, M. P., Luo, J., Zhang, L., Burdick, M.D., Lin, Y.Q., Dohadwala, M., Gardner, B., Batra, R. K., Strieter, R. M. and Dubinett, S. M. : IL-7 inhibits fibroblast TGF-beta production and signaling in pulmonary fibrosis. J. Clin. Invest. 109 : 931-937, 2002. 